\title{
South African Standards for Principals: Connecting Theory, Policy, Practice and Context
}

\author{
R.N. (Nylon) Marishane \\ Department of Education Management and Policy Studies, Faculty of Education, \\ Groenkloof Campus, University of Pretoria, 0002 South Africa \\ E-mail: nylon.marishane@up.ac.za
}

KEYWORDS Implementation Infrastructure. Leadership. Learning. School Improvement. Sustainability

\begin{abstract}
School improvement is admittedly the main business of school leadership. However, for such improvement to be sustained, a focus on the quality of school leadership is indispensable. To address the issue of leadership quality, the South African Department of Basic Education has introduced a policy on the standard for principalship. The policy outlines the standard a typical South African school principal is expected to meet. Underpinned by the assumption that improving the quality of school leadership requires a strong connection between leadership theory, policy, practice and context, this paper seeks to examine the implications of the new policy for the South African school principals. The paper is based on the review of the literature on leadership practices and the emerging standards for school leadership applied in selected countries. It highlights the importance of providing policy implementation infrastructure and concludes by suggesting possible strategies for effective implementation of the policy.
\end{abstract}

\section{INTRODUCTION}

It has now become generally accepted that school leadership is a pillar for school improvement and student learning. It is for this reason that as countries enter the era of standards-based accountability systems, the need for a school leadership that seeks to promote and sustain student learning and achievement becomes imperative. This view is supported by a plethora of theoretical and empirical studies, which collectively suggest that high academic standards demand high professional standards for school leadership (Ingvarson et al. 2006; Barber and Mourshed 2007; Pont et al. 2008; Gallie and Keevy 2014). The demand for high standards on both ends of the spectrum raises high stakes for global competitiveness for student academic outcomes. This global competitiveness, in turn, requires sharing best international practices, informed by empirically tested theories, which are appropriately adapted to the national context for success. To narrow the gap between theory and practice and contextualize the definition of the leadership standards, many countries have applied lessons derived from school leadership research findings (Leithwood et al. 2006; Mulford 2013) and other success stories (Drysdale et al. 2009; Day and Sammons 2013). This reinforces the author's view that a starting point for the development of a type of leadership needed for sustainable school improvement is the creation of a strong link between theory, practice, policy and the context in which such leadership should function. It is against this background that the South African Department of Basic Education (DBE) has developed a policy on the standard for principals. The policy is not confined to practice but is also infused through the education management and leadership programme initiated by the DBE (Department of Basic Education 2015) to create a platform from which the desirable school leadership standards can begin.

\section{METHODOLOGY}

This paper is based on the review of the literature on contemporary leadership theories and school management and leadership in the South African context. The purpose of this review shed light on the South African Policy on Standard for School Principals.

\section{OBSERVATIONAND DISCUSSION}

\section{Theoretical Grounding Underpinning Standards for School Leadership (SSL)}

Standards for school leadership (SSL) are informed by research into school leadership conducted in recent decades. Findings from the ex- 
haustive review of the literature as well as the meta-analysis of studies into successful leadership (Leithwood et al. 2004; Leithwood 2005; Leithwood et al. 2006; Day et al. 2011; Mulford 2013) have established a set of core practices carried out by school leadership with evidence of significant influence on organisational goals. Each of these practices is shaped by a set of leadership behaviours specific to that practice. Although the identification of these practices does not necessarily imply that every school leader applies them (Leithood et al. 2006), they have been found to be applicable to all organisational contexts (Gurr 2015). Leithwood et al. (2006: 34-43) have identified these practices as setting direction, developing people, restructuring the organisation and managing the instructional programme. These cross-contextual leadership practices are outlined in the next paragraph.

\section{Cross-Contextual Leadership Practices}

The following is a set of core leadership practices which underpin various school leadership theories. These practices, as grounded in the leadership theory, suggest that any principalship standards should embody them.

Setting Direction: This practice involves the leadership actions that relate to creating a shared vision, fostering collectively acceptable goals and setting high-performance expectations.

Developing People: This practice includes such actions as modelling appropriate behaviour, stimulating others intellectually, and providing individualized support and consideration.

Redesigning the Organisation: This practice involves: creating and putting structures in place for developing and sustaining collaborative culture, connecting the school to the broader environment, and building working relationships with families and communities.

Managing the Instructional Programme: The leadership actions belonging to this practice include providing the instructional programme with appropriate staff and support and protecting the programme from interruptions.

A remarkable feature of these practices is that they emerge from various theories within the framework of which they can best be explained. Owing to space constraints, only two examples of contemporary theories connected to the practices are cited here, namely, transformational leadership and instructional leadership.

\section{Transformational Leadership}

Transformational leadership, which was first introduced in political leadership studies (Burns 1978) before its extension to psychology (Bass 1985), focuses on the restructuring of organisational culture and the relationship between organisational leaders and their followers (Avolio et al. 1991). The primary role of the leader, according to the theory, is to restructure the organisation in such a manner that organisational members collectively reach "higher levels of morality and motivation” (Burns 1978: 20). This is made possible by forging positive relationships between leaders and followers, which occurs when leaders recognise followers' personal and professional interests and strive to satisfy them while, at the same time, these leaders behave in an exemplary manner so as to motivate followers to emulate them. More emphasis in this regard is placed on individual leaders' personality, behaviour and abilities, which are critical for the success of the organisational culture. The latter, according to the theory, is shaped by such leadership actions as an idealized influence, intellectual stimulation, inspirational motivation and individualized consideration (Bass 1999; Ahmad et al. 2014; Mokhber 2015). These actions relate closely with such core leadership practices as setting direction, developing people and redesigning the organisation and resonate well with the current standards for school principals applied in many parts of the world.

\section{Instructional Leadership}

Instructional leadership theory focuses on the main 'business' of school leadership, namely, teaching and learning with strong emphasis on teacher capacity. Based on Hallinger and Murphy's (1985) three-dimensional model and its improved version called shared instructional leadership (Lambert 2003; Marks and Printy 2003), instructional leadership presents leadership as consisting of three dimensions, namely, defining the school mission, managing the instructional (teaching and learning) programme and promoting the school climate. These dimensions show a connection between leadership for teaching and learning and school improvement - a subject covered by international studies (Bush et al. 2010). The main argument pushed 
by the instructional leadership theory is that for a school to succeed in achieving their outcomes, there should be a strong instructional leadership. The latter is defined as a leadership that supports teachers by creating an environment that is conducive to effective teaching and learning (Horng and Loeb 2010). With its emphasis on teacher capacity, instructional leadership covers all the four core leadership practices.

\section{Aligning Standards for School Leadership with Leadership Theory, Practice, Context and Policy}

With regard to standards for school leadership, there is a close connection between four key elements, namely, theory, practice, context and policy, which collectively revolve around a purpose. The sustainability of the move towards the achievement of purpose depends on the strength of the link between the elements as Figure 1 shows. The link (shown by a thick circle around the purpose) represents the quality of the principal or what could be regarded as characteristics common among good principals, according to an Australian study (Education Services Australia 2015). These characteristics include knowledge and comprehension, vision and values, social and communication skills and personal qualities.

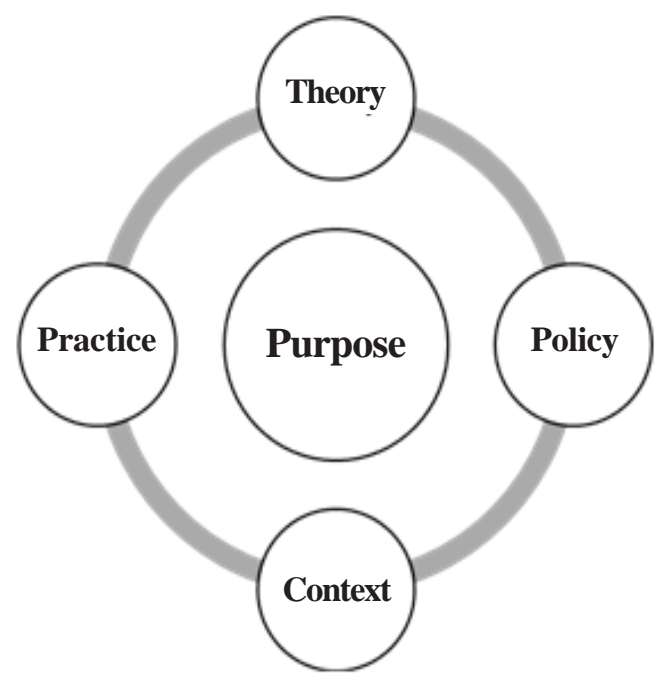

Fig. 1. Standards for principalship: Connecting the elements for the purpose Source: Author
The main motivation behind the development of school leadership standards is to develop school principals' competencies and behaviours which, according to literature, contribute positively to improved student learning and academic achievement (Robinson et al. 2009). How the combined behaviours and competencies are applied in practice is subject to various contexts and thus, their application differs from country to country. As an example of competencies, Table 1 shows the link between Leithwood and Friends' (2006) theory of core leadership practices and the domains in which principals carry out these practices as established by a recent study (Pont 2013).

Table 1: Core leadership practices and principalship domains

\begin{tabular}{|c|c|}
\hline $\begin{array}{l}\text { Core leadership } \\
\text { practices }\end{array}$ & Principalship domains \\
\hline Setting direction & $\begin{array}{l}\text { Establishment of a guiding } \\
\text { mission }\end{array}$ \\
\hline Developing people & $\begin{array}{l}\text { Development of the self and } \\
\text { others }\end{array}$ \\
\hline $\begin{array}{l}\text { Restructuring the } \\
\text { organisation }\end{array}$ & $\begin{array}{l}\text { Generation of organisational } \\
\text { conditions Creation har- } \\
\text { mony within the school }\end{array}$ \\
\hline $\begin{array}{l}\text { Managing the instruc- } \\
\text { tional programme }\end{array}$ & Pedagogical management \\
\hline
\end{tabular}

Source: Adapted from Leithwood et al. (2006) and Pont (2013)

As could be deduced from the table, both the core leadership practices and principalship domains reflect combined elements of theories of transformational leadership and instructional leadership. This suggests the importance of connecting the two theories in any policy that focuses on standards for school leadership.

\section{South African School Leadership and Policy on Standard for Principals}

In order to understand how standards for school leadership align with key aspects such as theory, practice, context and policy, it is important to discuss the South African context of school management and leadership, giving a brief background to the nature of the Policy on the South African Standard for School Principals (PSSPs). Such a discussion is followed by the implication of the policy for practice. 


\section{Management-Leadership Dichotomy Revisited in South Africa}

In school principalship, management and leadership are 'head-and-tail' faces of the same coin (Marishane 2011: 5). For many years the South African school principal has been viewed as a manager rather than a leader - as someone responsible and accountable for the management of physical, human, curriculum and financial resources devolved to the school level in line with the global decentralisation trends. Management of teaching and learning and management of school-community relations are examples of responsibilities assigned to school principals. This view of a principal as a school manager rather than a leader, which appears to lay more emphasis on accountability than creativity and innovation, has its roots in the education laws and policies which have emerged since the dawn of democracy in the country. For instance, nowhere in the South African Schools Act of 1996 (Department of Education 1996) is mention made of school leadership. No wonder emphasis has been placed on management functions of a school principal for some years. These functions are outlined in the Personnel Administrative Measures first published in 1999 (Department of Education 1999) and amended sixteen times since then (Department of Basic Education 2016). In addition to a one-sided focus on the school management role of the principal, the review of the South African literature shows lack of sufficient research into school management and leadership in the country (Bush and Glover 2014). It was only after 2007 that the concept of 'school leadership' started to emerge on the educational landscape as an additional professional role of the school principal. This development was articulated by the Department of Education's introduction of professional training for school principals in management and leadership offered through universities (Ngcobo 2012). Such training would lead to an Advanced Certificate in Education (ACE) for school leadership and management.

Though the concept 'leadership' was added to the training programme, more emphasis was placed on management than leadership (Kgwete 2014) and everything principals were expected to do in their schools was expressed in management terms. This was despite the criticism levelled against an emphasis on management at the expense of value-laden leadership of school principals mentioned in research (Day et al. 2001). The introduction of this type of training opened opportunities for research into school leadership and management (Bush et al. 2010; Christie 2010; Ngcobo 2012), which culminated in the review of the training programme (Department of Basic Education 2015) and the publication of a Policy on the South African Standard for Principals (Department of Basic Education 2016). Both the policy and the training are intended to restructure the context of school leadership in the country and align it with the changes taking place in the broader global context, by enhancing the competence and capacity of the school principal. The latter is identified as one of the key education priorities reflected in the National Development Plan (National Planning Commission 2013).

\section{Policy on the South African Standard for Principals}

The development of a policy on standards for school principals (PSSP) in South Africa coincides with the development of similar policies in other parts of the world (Condon and Clifford 2012; DfE 2015; Pont 2013). Underlying the development of these standards is the view that, since the performance of school leadership is a matter of paramount importance to student learning, it is essential to define what is expected from principals as school leaders and managers. Underpinned by a mix of social-educational and professional values and principles, the policy outlines the following eight (8) key areas regarded as fundamental for principalship:

- Leading teaching and learning in the school

- Shaping the direction and development of the school

- Managing quality of teaching and learning and securing accountability

- Developing and empowering staff and others

- Managing the school as an organization

- Working with and for the community

- Managing human resources in the school

- Managing and advocating extramural activities

Outlined under each key area are requisite actions and knowledge expected from a principal, that is, what the principal should know and do. For example, within the area 'Leading teach- 
ing and learning in the school', the policy stipulates fourteen (14) educational matters spread across instruction, technology learning, curriculum, and human resource management, which the principal is expected to know (Department of Basic Education 2016: 11). In addition, the principal is expected to demonstrate the stated knowledge by carrying out twenty-six (26) listed actions (Department of Basic Education 2016: 12). The eight key areas collectively contain a list of sixty-eight (68) different actions. Collectively these actions constitute a package of tasks that a serving school principal or anyone aspiring to become a principal is expected to carry out as part of their professional responsibilities. More emphasis is placed on management - particularly management of teaching and learning than on leadership.

\section{Practical Implications of the Policy on South African Standard for Principals}

The South African policy on standards for school principals has a number of implications for principals. The following four major implications emanating from the study of the policy are pertinent:

Giving a Narrow Space for Multiple Theories: Schools today are operating in a global context of constant flux and it is for this reason that school leadership that is geared towards continuous improvement, needs to be responsive to current leadership theories to meet the demands of this context. These theories include instructional leadership, transformational leadership, leadership for learning and others. While the policy recognizes the existence of different theories of leadership, it tends to push for the instructional leadership and this is not in concert with the dynamics of the current school context. For instance, while the instructional leadership is critical for student learning, such learning needs the creation of the organizational culture that fosters learning - something advocated by the transformational leadership theory (Harrison 2011). For school principals, advocating instructional leadership implies that consideration should be given to one theory, model or style that policy makers deem appropriate for the South African context. Research, however, shows that successful principalship is not an issue that can be sufficiently captured in a single leadership model (Gurr 2015). Since princi- pals have different leadership styles, encouraging them to apply a particular theory or style may negatively affect their effectiveness.

Laying Emphasis on Management: In terms of the plethora of the managerial responsibilities the scope of the policy covers more emphasis appears to be placed on management than leadership. Firstly, this does not auger well with existing global trends where the emphasis is placed on addressing the tension between management and accountability on the one hand and leadership and innovation on the other hand. Secondly, research shows that in their attempt to responds to managerial demands, principals are quite often distracted from a clear focus on instruction (Thrupp and Wilmot 2003). The distraction caused by a focus on managerial responsibilities quite often leads to stress and job dissatisfaction, according to a number of studies (Sodoma and Else 2009; Watson 2009). Lastly, because the provisions of the policy will be applied uniformly in the processes of recruiting, selecting and appointing new principals and possibly evaluating the performance of those who are currently in service, getting the right people for the job may be a challenge.

Prescribing Rather than Guiding Practice: The South African policy seems to be prescriptive rather than guiding practice. By listing actions that school principals should perform, the policy leaves little room for innovation. Innovation and taking risks in the best interest of student learning feature prominently as priorities for successful school leaders.

De-Contextualizing Principalship Actions: In its introduction, the policy recognizes the uniqueness of the South African educational context in terms of its "complex economic, political, social" and rural and urban factors (Department of Basic Education 2016: 3). This recognition is critical for the development of school principals. Despite this recognition, the standards for principals contained in the policy are intended to apply to all principals throughout the country regardless of the existing contextual differences and the uniqueness of each individual principal's preferences and style of leadership and management. However, research shows that leadership is context-bound (Turnbull James 2011) and that school contexts are complex and dynamic (Uhl-Bien et al. 2007). This implies that de-contextualizing principalship actions as the 
policy suggests, may create challenges relating to the effective implementation of the policy by principals working in different contexts.

\section{CONCLUSION}

This paper was based on the assumption that sustainable school improvement, which serves as the purpose of school leadership, requires a strong link between theory, practice, context and policy. With this assumption, the paper placed the South African Policy on Standard for Principals within the context of the international movement towards the establishment of standards for school leadership. It did this by first proceeding from the theoretical framework underpinning school leadership across various contexts and coupled this with a brief discussion on a couple of current theories on school leadership associated with successful school improvement. Based on the theoretical framework and the empirical evidence derived from the review of international literature on the standards for school leadership, the discussion focussed on the South African policy in relation to other policies to examine its implications for practice in South Africa. It emerged from the study that the South African policy does not show a clear connection between key elements that link the standards for leadership with the purpose the standards are intended to achieve. In this manner, the conclusion drawn verified the author's assumption.

\section{RECOMMENDATIONS}

The following set of recommendations needs to be considered during the policy's implementation and its possible review:

Extend the Standards beyond School Improvement: Literature abounds with numerous empirical studies and meta-analyses of successful leadership and effective schools. For instance, we now know that leadership affects student achievement. But, what is now raising interest is how to sustain academic achievement. To address this issue, school leadership studies are now shifting their focus from mere school improvement to sustaining such improvement. The focus of a policy on standards for principalship should, therefore, extend beyond improvement to cover sustainability and the De- partment of Basic Education should consider this in its implementation of PSSP.

Provide Policy Implantation Infrastructure and Capacity: For effective implementation of the PSSL, the Department of Basic Education needs to provide a policy implementation infrastructure. Such infrastructure needs to be mobilised through capacity building programmes for school principals aimed at the effective implementation of the policy.

Reinforce The Policy with Strong Connectivity and Flexibility: It is important for the PSSL practices to be connected to the leadership theory and the different contexts in which principals work. This suggests giving principals room for flexibility and creativity, enabling them to be innovative in their school leadership practices, guided by leadership theories relevant to their organisational context.

Shift Focus from School Management to Instructional Leadership: It is important for the PSSL to reflect a current shift in the approach to principalship, marked by a shift from a focus on school management to a focus on teaching and learning and the organisational conditions under which this occurs. To reflect this shift, the policy needs to focus on how the principal can carry out the practices and functions contained in the policy to impinge on teaching and learning effectively. This needs to be addressed through professional development emphasizing principals' capacity for effective instructional leadership.

\section{REFERENCES}

Ahmad F, Abbas T, Latif S, Rasheed A 2014. The impact of transformational leadership on employee motivation in telecommunication sector. Journal of Management Policies and Practices, 2(2): 1125.

Avolio BJ, Waldman DA, Yammarinno FJ 1991. Leading in the 1990s: The four I's of transformational leadership. Journal of European Industrial Training, 15(4): 9-16.

Barber M, Mourshed M 2007. How the World's Best Performing School Systems Come Out on Top. London: McKinsey \& Company.

Bass BM 1985. Leadership and Performance beyond Expectations. New York: The Free Press.

Bass BM 1999. Two decades of research and development in transformational leadership. European Journal of Work and Organizational Psychology, 8(1): 9-32.

Burns JM 1978. Leadership. New York: Harper \& Row.

Bush T, Glover D 2014. School leadership and management in South Africa: Findings from a systematic 
literature review. International Journal of Educational Management, 30(2): 211-223.

Bush T, Joubert R, Kiggundu E, Van Rooyen J 2010. Managing teaching and learning in South African schools. International Journal of Educational Development, 30(2): 162-168.

Christie P 2010. Landscapes of leadership in South African schools: Mapping the changes. Educational Management Administration \& Leadership, 38(6): 694-711.

Condon C, Clifford M 2012. Measuring Principal Performance: How Rigorous are Principal Performance Assessment Instruments? Washington, DC: American Institute for Research.

Day C, Harris A, Hadfield M 2001. Challenging the orthodoxy of effective school leadership. International Journal of Leadership in Education, 4(1): 39-56.

Day C, Sammons P 2013. Successful Leadership: A Review of the International Literature. Reading, Berkshire: CfBT Education Trust.

Day C, Sammons P, Leithwood K, Harris A, Hopkins D, Gu Q, Brown E, Ahtaridou E 2011. Successful School Leadership: Linking with Learning and Achievement. Berkshire, England: Open University Press.

Department of Basic Education 2015. Programme Outline for the Advanced Diploma in School Leadership and Management: Education and Management. Pretoria: Department of Basic Education.

Department of Basic Education 2016. Personnel Administrative Measures (PAM). Pretoria: Department of Basic Education.

Department of Education 1996. South African Schools Act. Act No. 84 of 1996. Pretoria: Government Printers.

Department of Education 1999. Personnel Administrative Measures (PAM). Pretoria: Department of Education.

DfE 2015. National Standards of Excellence for Headteachers. London: Department of Education.

Drysdale L, Goode H, Gurr D 2009. An Australian model of successful school leadership: Moving from success to sustainability. Journal of Educational Administration, 47(6): 697-708.

Education Services Australia 2015. Australian Professional Standards for Principals and the Leadership Profiles. Carlton South, VIC.: Education Council Secretariat.

Gallie M, Keevy J 2014. Standards Framework for Teachers and School Leaders. Report prepared for the Commonwealth Secretariat, London.

Gurr D 2015. A model of successful school leadership from the international successful school principalship project. Societies, 5: 136-150. doi: 10.3390/ soc5010136.

Hallinger P, Murph J 1985. Instructional Effectiveness and School SES: Is Good for the Goose, Good for the Gander? Paper presented at the Annual Meeting of the American Educational Research Association (AERA). March, Chicago.

Harrison JL 2011. Instructor transformational leadership and student outcomes. Emerging Leadership Journeys, 4(1): 82- 136.

Horng E, Loeb S 2010. New thinking about instructional leadership. Kappan, 92(3): 66-69.
Ingvarson L, Anderson M, Gronn P, Jackson A 2006. Standards for School Leadership: A Critical Review of the Literature. From <http://research.acer.edu.au/ teaching_standards/3>.

Kgwete EM 2014. Understanding School Leadership: A Study of ACE School Leadership Programme and Leadership Practices. MEd Dissertation, Unpublished. Pretoria: University of Pretoria.

Lambert L 2003. Leadership Capacity for Lasting School Improvement. Alexandria, VA: Association for Supervision and Curriculum Development.

Leithwood K 2005. Educational Leadership: A Review of the Research. Report prepared for Student Success. Toronto: The Mid-Atlantic Regional Educational Laboratory at Temple University Centre for Research in Human Development and Education, Temple University.

Leithwood K, Louis KS, Anderson S, Wahlstrom K 2004. Review of Research: How Leadership Influences Student Learning. New York: Wallace Foundation.

Leithwood K, Day C, Sammons P, Harris A, Hopkins D 2006. Seven Strong Claims about Successful School Leadership. Nottingham, England: National College of School Leadership.

Marishane RN 2011. School Leadership in a Changing Context: A Case for School-based Management. Pretoria: Van Schaik Publishers.

Marks HM, Printy SM 2003. Principal leadership and school performance: Integrating transformational and instructional leadership. Educational Administration Quarterly, 39: 370-397.

Mokhber M, Khairuzzaman bin Wan Ismail W, Vakilbashi A 2015. Effect of transformational leadership and its components on organizational innovation. Iranian Journal of Management Studies, 8(2): 221-241.

Mulford B 2013. Successful school leadership for improved student outcomes: Capacity building and synergy. International Journal of Educational Leadership and Management, 1(1): 7-32.

National Planning Commission 2013. National Development Plan 2030: Our future - Make it Work. Pretoria: The Presidency.

Ngcobo T 2012. Leadership development challenges in South African schools: The advanced certificate: Education (School Management and Leadership). Africa Education Review, 9(3): 417-433.

Pont B 2013. Learning Standards, Teaching Standards and Standards for School Principals: A Comparative Study. OECD Working Papers No.99. From $<$ www.oecd.or/edu/workingpaper> (Retrieved on 25 March 2016).

Pont B, Nusche D, Moorman H 2008. Improving School Leadership. Volume 1: Policy and Practice. OECD. From <http://dx.doi.org/10.1787/978926 4044715en>.

Robinson V, Hohepa M, Lloyd C 2009. School Leadership and Student Outcomes: Identifying What Works and Why. New Zealand: Best Evidence Synthesis Iteration [BES], New Zealand Ministry of Education.

Sodoma B, Else D 2009. Job satisfaction on Iowa public school principals. The Rural Educator, 3(1): 10-18. 
Thrupp M, Wilmot W 2003. Education Management in Managerial Times. Philadelphia, PA: Open University Press.

Turnbull James K 2011. Leadership in Context: Lessons from New Leadership Theory and Current Leadership Development Practice. London: The King's Fund.

Uhl-Bien M, Marion, McKelvey B 2007. Complexity leadership theory: Shifting leadership from the industrial age to the knowledge era. The Leadership Quarterly, 18(4): 298-318.

Watson L 2009. Leadership's influence on job satisfaction. Journal of Radiologic Technology, 80(4): 297-308.

Paper received for publication on June 2016

Paper accepted for publication on October 2016 